\title{
Assessing Key Factor that Influence on the Acceptance of Mobile Commerce Based on Modified UTAUT
}

\author{
Mohammed-Issa Riad Mousa Jaradat ${ }^{1} \&$ Mamoun S. Al Rababaa ${ }^{2}$ \\ 1 Department of Information Systems/Management Information Systems, Faculty of Prince Hussein Bin \\ Abdullah for Information Technology, Al al-Bayt University, Jordan \\ ${ }^{2}$ Department of Computer Science, Faculty of Prince Hussein Bin Abdullah for Information Technology, Al \\ al-Bayt University, Jordan \\ Correspondence: Mohammed-Issa Riad Mousa Jaradat, Department of Information Systems/Management \\ Information Systems, Faculty of Prince Hussein Bin Abdullah for Information Technology, Al al-Bayt \\ University, Jordan. E-mail: mi_jaradat@aabu.edu.jo
}

Received: September 17, 2013

Accepted: October 8, 2013 Online Published: November 15, 2013

doi:10.5539/ijbm.v8n23p102

URL: http://dx.doi.org/10.5539/ijbm.v8n23p102

\begin{abstract}
This study presents a modified Unified Theory of Acceptance and Use of Technology (UTAUT) to examine key factors that affect the intention to accept and the subsequent use of mobile commerce (M-commerce) among Jordanian consumers. A survey questionnaire was used to collect data from 447 undergraduate university students using a stratified random sample, and analyzed by using a structural equation modeling (SEM); by using the WarpPLS 3.0 software. Results show that user acceptance and use of Mobile commerce services can be predicted from the users' behavioral intentions, which are affected significantly by Performance Expectancy, Effort Expectancy, and Social Influence. From among these variables, Social Influence is the most significant determinant that directly affects behavioral intention to use M-commerce services in Jordan followed by Effort Expectancy then Performance Expectancy. Facilitating Conditions and moderating variables (gender, age, monthly expense, and experience) have no significant effect on Behavioral Intention to use M-commerce services in Jordan.

Ultimately, this study finds that there is a direct effect between behavioral intention and the eventual use of M-commerce services in Jordan. This research should help merchandisers avoid spending thousands or even millions of dollars that may on investments that will have little effect on whether or not the consumer will actually accept and use M-commerce. The study also gives quantified indicators and presents a model that might help in understanding the M-commerce environment in Jordan. It concludes with an examination of the implications of the research findings and offers suggestions for future research.
\end{abstract}

Keywords: mobile commerce (M-commerce), unified theory of acceptance and use of technology (UTAUT), social influence (SI), facilitating conditions (FC)

\section{Introduction}

Technologies have a deeply strong impact on our lives. Je Ho and Myeong-Cheol (2005) claimed that the use of internet via wired network changed the way of delivering, it becomes effective and easy. However the use of wireless device is expected to deliver information and services at anytime and anywhere for individuals.

Economides and Grousopoulou (2010, p.1) claimed that "Mobile devices have become some of the fastest advancing communication gadgets". Mulliah and Stroulia (2009, p.1) claimed that "Mobile devices are becoming increasingly powerful and accessible as wireless networks cover most of our daily environment and a variety of software frameworks".

In Jordan, there are 388,029 fixed telephone lines and 9,955,792 mobile lines which exceed the total population of the country (Telecommunication Regulatory Commission Jordan, 2013). This indicates that mobile phones are increasing continuously and rapidly and no longer considered just a fashion for our lives, but are now deemed a necessity.

Mobile commerce (M-commerce) refers to the use of mobile devices or mobile equipment to buy and/or sell products, services, or information at anytime, anywhere via a wireless network. Chaffey (2009, p.6) defines 
Mobile commerce or M-commerce as "electronic transactions and communications conducted using mobile devices such as laptops, PDAs, and mobile phones, and typically with a wireless connection". Due to the spread, acceptance, adoption, and usage of the means of mobile communication in both the developed and developing countries M-commerce aims to increase the participation of merchandisers and shoppers. For example, they will be able to use wireless devices for accessing banking accounts (check balances, transfer money, etc.), buying and/or selling products, services, and/or information at any time anywhere.

M-commerce is a new innovation in business that will transform the way organizations conduct their business even between business and business (B2B) or between business and consumers (B2C) and change the relationships between stakeholders (Anckar et al., 2003).

Abdelkarim and Nasereddin (2010) showed that M-commerce is a subset of E-commerce where mobile devices are used to conduct business. They claimed that because of the wide spread of mobile phones; M-commerce services have a prosperous future. Traditional business processes caused in general delay in business transactions; companies try to reduce that delay by creating easier access to information in a real time environment and to explore new business opportunities. The researchers found positive attitudes toward M-commerce by Jordanians. Furthermore, Jordanians perceive M-commerce as highly useful and easier than the traditional methods of commerce.

Chaffey (2009) illustrated five benefits that mobile or wireless connections offer to their users. Ubiquity: Information can be accessed from anywhere, at any location, and at any time. Reachability: the users of M-commerce can be reached outside of their normal, or home, location. Convenience: Mobile devices make it unnecessary to have access to a power supply or fixed-line connection. Security: Each user can be authenticated since each wireless device has a unique identification code enabling the commerce provider to tailor content based on the customer's location. Mobile devices also provide a degree of privacy compared with a desktop PC. Finally, instant access or being "always-on": There is no need to dial up a wireless connection with a mobile device.

Je Ho and Myeong-Cheol (2005) found that attitude toward mobile internet is the most significant determinant followed by the perceived playfulness and the usefulness to use M-Internet. In turn, perceived ease of use was found to have critical significant influence in developing the perceived usefulness and playfulness.

Park et al. (2007) applied the UTAUT model to M-commerce adoption behavior in Chinese consumers. In their research, Performance Expectancy, Effort Expectancy, Social Influence, and Facilitating Condition are significant factors that influenced the adoption of M-commerce. In turn, moderating factors gender and education level was found to have a significant influence. However, Internet usage experience has no significant effect on the adoption of M-commerce among Chinese consumers. Qingfei et al. (2008) said that "user acceptance is one of the key fundamentals for the development and success of M-commerce". Moreover, Nor Shahriza et al. (2006) claimed that positive perceptions might be leaded due to the widespread use of mobile phones applications among students.

\subsection{Problem Statement}

Because of the widespread of mobile devices; merchandisers in Jordan should change and follow the new innovation in business such as M-commerce. This change could cause thousands or even millions of dollars that may on investments that will have little effect on whether or not the consumer will actually accept and use. Therefore, the present study aims to explore the factors that affect the intention to accept and the subsequent use of M-commerce among Jordanian consumers. The study also gives quantified indicators and presents a model that might help in understanding the M-commerce environment in Jordan.

\section{Theoretical Background}

This study investigates the key factors that affect the intention to accept and the subsequent use of M-commerce among Jordanian consumers. This research will evaluate the effects of these factors by using a modified Unified Theory of Acceptance and Use of Technology (UTAUT).

The Unified Theory of Acceptance and Use of Technology (UTAUT) depicted in Figure 1, was developed by Venkatesh et al. (2003) for the purpose of examining technology acceptance and adoption using a more unified approach. The model integrates the Perceived Usefulness (PU) and Perceived Ease of Use (PEOU) of the Technology Acceptance Model (TAM) by Davis (1989), referring to them as Performance Expectancy (PE) and Effort Expectancy (EE). In addition to these two variables: Social Influence (SI) and Facilitating Condition (FC). Gender, age, experience, and voluntariness of use are hypothesized to mediate the impact of the four key constructs on usage intention and behavior. 


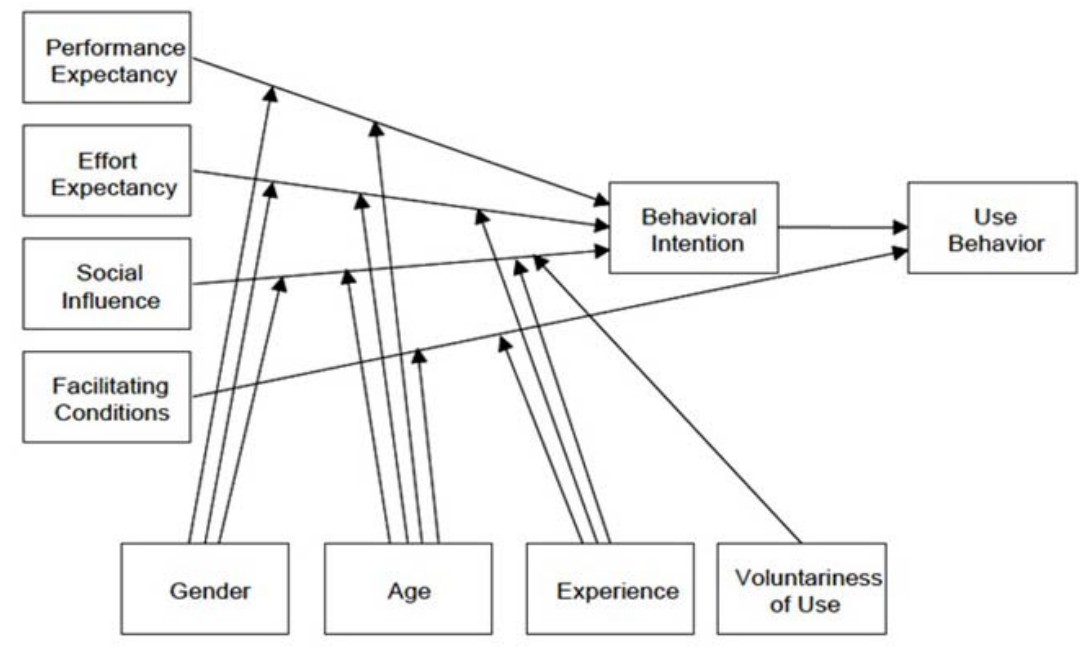

Figure 1. Original unified theory of acceptance and use of technology (UTAUT)

\section{Research Model and Hyphotheses Development}

\subsection{Performance Expectancy in Mobile Commerce Technology}

Performance expectancy (PE) is defined as the "degree to which an individual believes that using the system will help him or her attain gains in job performance" (Venkatesh et al. 2003, p. 447). According to Venkatesh et al. (2003), the researchers assumed that the relationship between PE and BI will be moderated by both gender and age in favor of the younger men than women. They claimed that new information systems such as M-commerce are difficult to use and less useful for the older end-users. Thus this research proposes the following hypotheses:

H1: Performance Expectancy has a positive effect on the Behavioral Intention to use M-commerce in Jordan.

H2: The relationship between Performance Expectancy and Behavioral Intention to use M-commerce in Jordan is moderated by the gender of users.

H3: The relationship between Performance Expectancy and Behavioral Intention to use M-commerce in Jordan is moderated by the age of users.

H4: The relationship between Performance Expectancy and Behavioral Intention to use M-commerce in Jordan is moderated by the monthly expense of users.

\subsection{Effort Expectancy in Mobile Commerce Technology}

Effort Expectancy (EE) is defined as "the degree of ease associated with the use of the system" (Venkatesh et al. 2003, p. 450). According to Venkatesh et al. (2003), they claimed that higher level of computer anxiety, ease of use and level of effort expectancy for new information systems such as M-commerce are in favor of the women than men. (Venkatesh and Morris, 2000) found that experience as a moderating factor has a significant effect over the long time the user use the system such as M-commerce. Therefore, the influence of EC on BI will be moderated by gender, age, and experience, in favor of the younger women than men at early stages. Thus this research proposes the following hypotheses:

\section{H5: Effort Expectancy has a positive influence on the Behavioral Intention to use M-commerce in Jordan.}

H6: The relationship between Effort Expectancy and Behavioral Intention to use M-commerce in Jordan is moderated by the gender of users.

H7: The relationship between Effort Expectancy and Behavioral Intention to use M-commerce in Jordan is moderated by the age of users.

H8: The relationship between Effort Expectancy and Behavioral Intention to use M-commerce in Jordan is moderated by the monthly expense of users.

H9: The relationship between Effort Expectancy and Behavioral Intention to use M-commerce in Jordan is moderated by the experience of users. 


\subsection{The Effect of Effort Expectancy on Performance Expectancy in Mobile Commerce Technology}

As a contribution, the effect of Effort Expectancy (Perceived Ease of Use) on Performance Expectancy in M-commerce Technology was hypothesized. Thus this research proposes the following hypothesis:

H20: Effort Expectancy has a positive influence on the Performance Expectancy of Using M-commerce in Jordan.

\subsection{Social Influence in Mobile Commerce Technology}

Social influence is defined as "the degree to which an individual perceives that important others believe he or she should use the new system" (Venkatesh et al. 2003, p. 451). "Important others" might include bosses, peers, subordinates, etc. Venkatesh et al. (2003) showed that social influence is characterized as subjective norm in TRA, TAM2, TPB/DTPB and C-TAM-TPB, social factors in MPCU, and image in IDT. Nysveen et al. (2005) indicate that social influence is a significant factor in term of the use mobile services. O'Reilly and Chatman (1986) claimed that social influence affects the person's commitment to use the information system (i.e. M-commerce). Malhotra and Galletta (1999) found that "social influences play an important role in determining the acceptance and usage behavior of new adopters of new information technologies". ORJI (2010) found that social influence is one of the most critical components in determining the acceptance and usage behavior. Tella (2011) found that ease of use, perceived usefulness, actual use, satisfaction, relevance, awareness, computer/internet self-efficacy, and social influence significantly correlate with E-commerce acceptance.

Venkatesh et al. (2003) expect that the influence of SI on BI will be moderated by gender, age, voluntariness, and experience, in favor of the older women than men in the early stages. Thus this research proposes the following hypotheses:

H10: Social Influence has a positive influence on the Behavioral Intention to use M-commerce in Jordan.

H11: The relationship between Social Influence and Behavioral Intention to use M-commerce in Jordan is moderated by the gender of users.

H12: The relationship between Social Influence and Behavioral Intention to use M-commerce in Jordan is moderated by the age of users.

H13: The relationship between Social Influence and Behavioral Intention to use M-commerce in Jordan is moderated by the monthly expense of users.

H14: The relationship between Social Influence and Behavioral Intention to use M-commerce in Jordan is moderated by the experience of users.

\subsection{Facilitating Conditions in Mobile Commerce Technology}

Facilitating conditions (FC) are defined as "the degree to which an individual believes that an organizational and technical infrastructure exists to support use of the system" (Venkatesh et al. 2003, p. 453). Technical infrastructure includes computer hardware and software necessary to utilize M-commerce. The influence of FC on usage will be moderated by age, monthly expense, and experience in favor of the older workers with increasing experience. Thus this research proposes the following hypotheses:

H15: Facilitating conditions will have a positive influence on usage of M-commerce in Jordan.

H16: The relationship between Facilitating conditions and usage of M-commerce in Jordan is moderated by the age of users.

H17: The relationship between Facilitating conditions and usage of M-commerce in Jordan is moderated by the monthly expense of users.

H18: The relationship between Facilitating conditions and usage of M-commerce in Jordan is moderated by the experience of users.

\subsection{Behavioral Intention}

Behavioral Intention (BI) is defined by (Fishbein and Ajzen, 1975; Fishbein and Ajzen, 1979; and Davis and Cosenza, 1993) as the degree to which M-commerce user's motivations intend to accept and use the system and this is our ultimate goals and aspirations. Venkatesh et al. (2003), assume that BI will have a significant positive influence on technology usage. Thus this research proposes the following hypothesis:

H19: Behavioral intention will have a significant positive influence on usage of M-commerce in Jordan. 


\section{Research Model and Hypotheses}

\subsection{Research Model}

The present study uses a modified UTAUT. The research model tested in this study is shown in Figure 2.

\subsection{Research Hypotheses}

This section presents the hypotheses to be tested and their relationship by using a modified Unified Theory of Acceptance and Use of Technology (UTAUT), as shown in Figure 2.

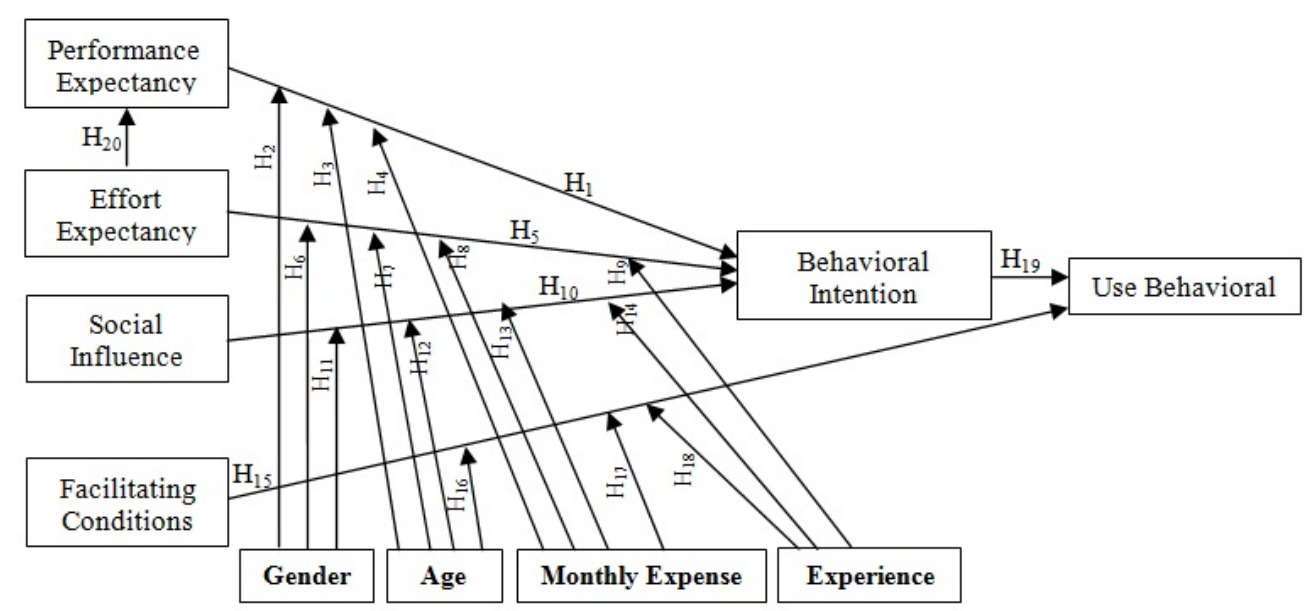

Figure 2. Proposed research model for M-commerce acceptance

\section{Research Design and Method}

\subsection{Population and Sample}

This study was conducted at Jordan public universities which have an approximate enrollment of 167,551 see Table 1 (Jordan public universities/ admission and registration department). The data was randomly collected from undergraduate students who had been personally given a survey questionnaire by using a stratified random sample. Yap and Hii (2009) claimed that because of income potential and educational level, university students are more likely to be the leading adopters for a new technology such as M-commerce. In Jordan, universities students are from various Jordanian's governorates; this implies there is a multiplicity of habits, traditions, culture and income. According to Sekaran (2006), a sample of 447 students was selected for this study.

Table 1. Public universities in Jordan

\begin{tabular}{rlrr}
\hline \multicolumn{1}{c}{$\#$} & University Name & Number of students & Percentage \\
\hline 1 & Jordan University & 35,099 & $20.9 \%$ \\
2 & Hashemite University & 22,943 & $13.7 \%$ \\
3 & Al Balqa Applied University & 8,746 & $5.2 \%$ \\
4 & Yarmouk University & 33,500 & $20 \%$ \\
5 & Jordan University for Science and technology & 22,600 & $13.5 \%$ \\
6 & Al al-Bayt University & 13,350 & $7.8 \%$ \\
7 & Mutah University & 17,890 & $10.7 \%$ \\
8 & Al-Hussein Bin Talal University & 7,498 & $4.5 \%$ \\
9 & Tafila Technical University & 5,925 & $3.5 \%$ \\
10 & German Jordanian University & 2,400 & $1 \%$ \\
\hline \multicolumn{2}{r}{} & Total
\end{tabular}

\subsection{Measuring the Constructs}

The study used a survey questionnaire based on previous studies for the purpose of data collection. The study 
adapted a measurement items from previously validated measures (i.e., Davis, 1989; Venkatesh et al., 2003). The measurement was designed using a five-point Likert scale ranging from (1) strongly disagree to (5) strongly agree. The questionnaire was pre-tested among the teachers and students. The questionnaire statements were modified based on the results of the pre-test.

\subsection{Data Collection Procedure}

In order to test the proposed model, quantitative was utilized. The questionnaire was distributed to a representative sample. All participants were selected from the Universities randomly by using a stratified random sample.

\subsection{Data Analysis}

The data for this research has been collected by using a questionnaire containing 20 questions. After the follow-up activities from 447 survey respondents, 382 returned the questionnaires. Seven questionnaires were dropped from the study because of incomplete answers. This left 375 sets of data for statistical analysis, with an $83.9 \%$ valid return rate. Structural equation modeling (SEM) using the WarpPLS 3.0 software that applies the partial least squares (PLS) technique was used for the analysis.

\subsection{Reliability and Validity}

Cronbach's alpha was used in this study to evaluate the internal consistency of the scale measurement and research variables. The results presented in Table 2 suggested that all the measures in this study ranged from 0.69 to 0.82 were reliable as recommended by Hair, Babin, Money, and Samouel (2003).

To assess the validity, a questionnaire was distributed to a selection of referees and a group of participants, and both of them agreed that the questionnaire measured the attributes it intended to measure.

Table 2. The Alpha coefficients

\begin{tabular}{lcl}
\hline & Variable & Alpha \\
\hline 1 & Performance Expectancy & 0.799 \\
2 & Effort Expectancy & 0.771 \\
3 & Social Influence & 0.693 \\
4 & Facilitating Conditions & 0.702 \\
5 & Behavioral Intonation & 0.818 \\
6 & Use Behavioral & 0.701 \\
\hline
\end{tabular}

\section{Results}

\subsection{Descriptive Statistics (Demographic Profile of Respondents)}

The demographic profile of the sample is illustrated in Table 3: participants in the study were composed of $56.8 \%$ male and 34.2 female. $62.1 \%$ were students in the age of 20 - Less than 25 years old range; 118 (31.5\%) were less than 20 years old; 24 (6.4\%) were more than 25 years old. The results indicated that monthly expenses with 50 - Less than $100 \mathrm{JD}$ of the respondents with $42.4 \%$, 86 when the monthly expenses are 100- Less than 200 JD with $22.9 \%$, 67 when the monthly expenses more than 200 with $17.9 \%$, 63 with monthly expenses that are Less than 50 with $16.8 \%$.

Table 3. Demographic profile

\begin{tabular}{cccc}
\hline & Variable & Frequency & Percentage \\
\hline \multirow{3}{*}{ Gender } & Female & 162 & 34.2 \\
& Male & 213 & 56.8 \\
\multirow{3}{*}{ Age (years) } & Less than 20 & 118 & 31.5 \\
& 20- Less than 25 & 233 & 62.1 \\
& More than 25 & 24 & 6.4 \\
& Less than 50 & 63 & 16.8 \\
Monthly expense & 50- Less than 100 & 159 & 42.4 \\
& 100- Less than 200 & 86 & 22.9 \\
& More than 200 & 67 & 17.9 \\
\hline
\end{tabular}




\subsection{Grand Mean for the Scores of Responses for All Study Variables}

Table 4 illustrates the grand mean for the scores of responses for all the study variables statements. When this grand mean is compared with the 5-point scale (High $>3$, Neutral $=3$, and Low $<3$ ), it was found that results of the respondent's categorization of the main study is greater than the agreement point $(+3)$. Therefore, this means all the study variables under the category "High" except for Social Influence which falls under the category "Low".

Table 4. Variables, grand mean

\begin{tabular}{lll}
\hline No. & Variable & Grand Mean \\
\hline 1 & Performance Expectancy & 3.43 \\
2 & Effort Expectancy & 3.42 \\
3 & Social Influence & 2.95 \\
4 & Facilitating Conditions & 3.27 \\
5 & Behavioral Intonation & 3.10 \\
6 & Use Behavior & 3.12 \\
\hline
\end{tabular}

\subsection{Hypotheses Test}

The model included 20 items describing six latent constructs: Performance Expectancy, Effort Expectancy, Social Influence, Facilitating Conditions, Behavioral Intonation, and Use Behavioral. The structural equation modeling (SEM) using the WarpPLS 3.0 software was used that applies the partial least squares (PLS) technique (http://www.scriptwarp.com/warppls). The measurement model test presented a good fit between the data and the proposed measurement model. To assess the model fit with the data, it is recommended that the $\mathrm{p}$-values for both the average path coefficient $(\mathrm{APC}=0.125, \mathrm{P}<0.001)$ and the average $\mathrm{r}$-squared $(\mathrm{ARS}=0.357, \mathrm{P}<0.001)$ be both lower than 0.05 . In addition, it is recommended that the average variance inflation factor (AVIF=1.484) be lower than 5 (Kock, 2009). So, the model has a good fit to the data. The various goodness-of-fit statistics are shown in Table 5.

Table 5. Model evaluation overall fit measurement

\begin{tabular}{lll}
\hline Measure & Value & P values \\
\hline Average path coefficient (APC) $(<0.05)$ & 0.125 & $\mathrm{P}<0.001$ \\
Average r-squared (ARS) $(<0.05)$ & 0.357 & $\mathrm{P}<0.001$ \\
Average variance inflation factor (AVIF) & 1.484 & Good if $<5$ \\
\hline
\end{tabular}

Convergent validity was evaluated to validate the measurement model through investigation composite reliability (CR) and average variance extracted (AVE). Table 6 illustrates that all CR and AVE values meet the recommended threshold values. On behalf of CR values are recommended to exceed 0.70 (Chin, Marcolin and Newsted, 2003) and AVE values should be greater than 0.50 (Fornell and Larcker, 1981). As shown in Table 6, discriminant validity was evaluated by obtaining the AVE values for each variable (Campbell, 1960). The square root of AVE for each variable is greater than the correlations between the variables and all other variables in the model, signifying that these variables have discriminant validity (Fornell and Larcker, 1981). Variance inflation factors (VIFs) were evaluated to check for the existence of collinearity. VIFs values less than 5 propose no collinearity (Hair et al., 2009; Kline, 1998). As shown in Table 6, All VIFs values meet the recommended threshold values. Based on the current findings, this study demonstrates that the proposed model exhibits adequate reliability, construct validity and collinearity. 
Table 6. Composite reliability, VIF, AVE, and correlation of constructs values

\begin{tabular}{|c|c|c|c|c|c|c|c|c|c|c|}
\hline & & $\begin{array}{l}\text { Composite } \\
\text { Reliability }\end{array}$ & VIFs & AVE & 1 & 2 & 3 & 4 & 5 & 6 \\
\hline 1 & Performance Expectancy & 0.869 & 1.621 & 0.625 & 0.791 & & & & & \\
\hline 2 & Effort Expectancy & 0.853 & 2.143 & 0.593 & 0.549 & 0.770 & & & & \\
\hline 3 & Social Influence & 0.813 & 1.567 & 0.524 & 0.278 & 0.291 & 0.724 & & & \\
\hline 4 & Facilitating Conditions & 0.808 & 1.847 & 0.514 & 0.328 & 0.585 & 0.327 & 0.717 & & \\
\hline 5 & Behavioral Intonation & 0.892 & 2.234 & 0.734 & 0.387 & 0.448 & 0.496 & 0.465 & 0.857 & \\
\hline 6 & Use Behavioral & 0.745 & 1.973 & 0.598 & 0.389 & 0.422 & 0.451 & 0.366 & 0.646 & 0.773 \\
\hline
\end{tabular}

Note: Square roots of the AVE are the bolded diagonal values.

Figure 3 presents the empirical results for the study. The hypotheses $\left(\mathrm{H}_{1}, \mathrm{H}_{5}, \mathrm{H}_{10}, \mathrm{H}_{19}\right.$, and $\left.\mathrm{H}_{20}\right)$ were strongly supported. However $\left(\mathrm{H}_{2}, \mathrm{H}_{3}, \mathrm{H}_{4}, \mathrm{H}_{6}, \mathrm{H}_{7}, \mathrm{H}_{8}, \mathrm{H}_{9}, \mathrm{H}_{11}, \mathrm{H}_{12}, \mathrm{H}_{13}, \mathrm{H}_{14}, \mathrm{H}_{15}, \mathrm{H}_{16}, \mathrm{H}_{17}\right.$, and $\left.\mathrm{H}_{18}\right)$ are not supported, the result indicated that Performance Expectancy of M-commerce services has a significant effect on behavioral intention to use $\mathrm{M}$-commerce services $\left(\mathrm{H}_{1}: \beta=0.18, \mathrm{P}<0.05\right)$, Moreover, it does have a significant indirect effect on both behavioral intention to use and actual use through Effort Expectancy of M-commerce services, and also has a significantly positive direct effect on Performance Expectancy of M-commerce services $\left(\mathrm{H}_{20}: \gamma=0.55\right.$, $\mathrm{P}<0.001$ ). The data also shows that Effort Expectancy significantly directly influences the behavioral intention to use $\left(\mathrm{H}_{5}: \beta=0.26, \mathrm{P}<0.001\right)$ and indirectly influences actual use. For hypothesis 10 , the social influence has a significant direct effect on the behavioral intention to use M-commerce services $\left(\mathrm{H}_{10}: \beta=0.40, \mathrm{P}<0.001\right)$. For hypothesis 15 which is proposed that Facilitating Conditions has a direct effect on behavioral intention to use M-commerce in Jordan, the data shows that it is not supported $\left(\mathrm{H}_{15}: \beta=0.06, \mathrm{P}>0.05\right)$. According to moderating variables (gender, age, monthly expense, and experience) the result indicated that they are not supported $\left(\mathrm{H}_{2}, \mathrm{H}_{3}\right.$, $\mathrm{H}_{4}, \mathrm{H}_{6}, \mathrm{H}_{7}, \mathrm{H}_{8}, \mathrm{H}_{9}, \mathrm{H}_{11}, \mathrm{H}_{12}, \mathrm{H}_{13}, \mathrm{H}_{14}, \mathrm{H}_{15}, \mathrm{H}_{16}, \mathrm{H}_{17}$, and $\mathrm{H}_{18}$ ).

As an ultimate aspiration, it was found that there is a direct effect between behavioral intention to use M-commerce services in Jordanian public universities and actual behavioral use $\left(\mathrm{H}_{19}: \beta=0.61, \mathrm{P}<0.001\right)$. This means that users' behavioral intention is an important determinant of system acceptance and usage.

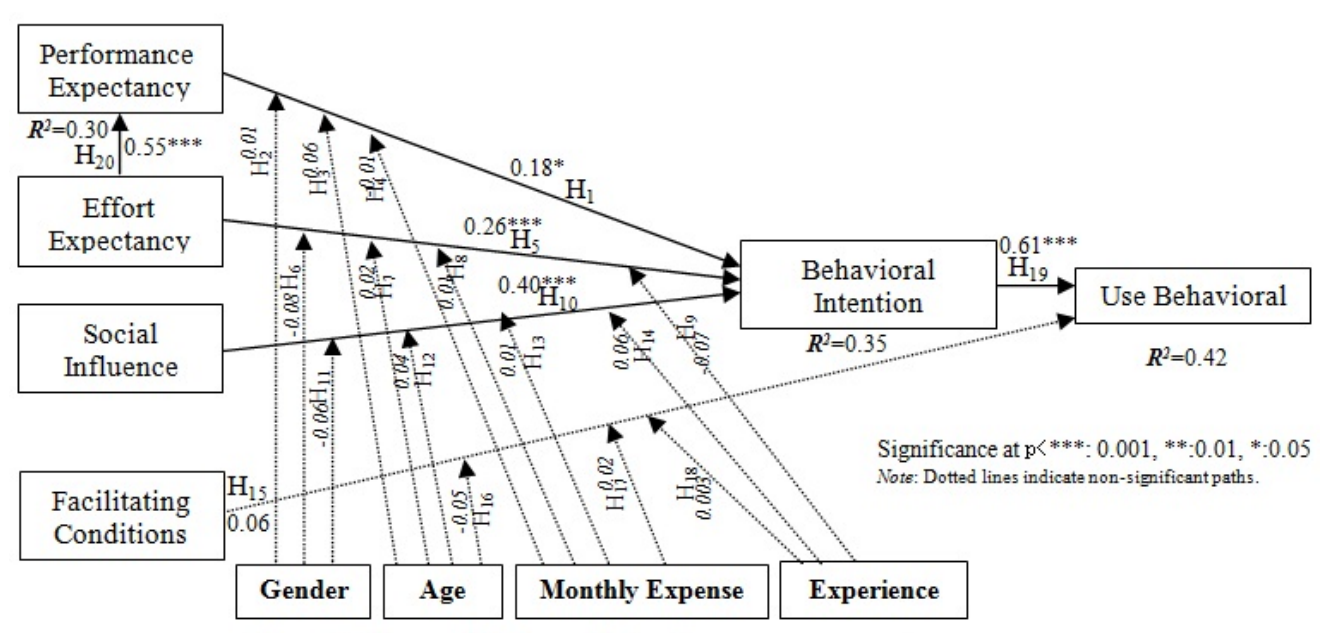

Figure 3. The empirical results for M-commerce acceptance

\section{Discussion and Conclusions}

The purpose of this article is to assess the key factor that influence on the acceptance of M-commerce in Jordan. For this purpose, a simple model based on a modified Unified Theory of Acceptance and Use of Technology (UTAUT) was developed and measured.

The results suggest that: First, user acceptance and use of M-commerce services can be predicted from the users' Behavioral Intentions, which are affected significantly by Performance Expectancy, Effort Expectancy, and Social Influence, and among these variables, Social Influence is the most significant determinant that directly 
affects behavioral intention to use M-commerce services in Jordan. The next two most significant determinants were Effort Expectancy and Performance Expectancy.

This indicates that consumers in Jordan are affected by the thoughts and actions of others regarding the use of M-commerce services. Our findings support prior studies such as (Malhotra et al., 1999; Nysveen et al., 2005; ORJI, 2010; Priyambodo et al., 2012; Tella, 2011; Thakur and Srivastava, 2013; Venkatesh et al., 2003). Second, the results show that Effort Expectancy has a more significant direct impact on behavioral intention than does Performance Expectancy. Cho et al. (2007) claimed that some research has found that the Effort Expectancy is stronger than the Performance Expectancy as a predictor of user acceptance. They claimed, "If consumers seek self-fulfilling value or hedonic-oriented product, perceived ease of use would have more important value affecting the intended use than perceived usefulness (p.4)." This result indicates that M-commerce developers should keep developing user oriented easy-to-use and user friendly interfaces in general the system should be easy-to-use. A possible explanation of these finding is that M-commerce is still in its infancy in Jordan and the consumers want to accept and use the new technology (M-commerce) without any effort. This result agrees with previous study such as (Liu et al., 2010). Third, Performance Expectancy has a significant effect on Behavioral Intention to use M-commerce services. This result indicates that Jordanian consumer intentions to use M-commerce services are positive and they expect its performance. This result agrees with previous study such as Abdelkarim and Nasereddin (2010). Moreover, it has a significant indirect effect on both Behavioral Intention to use and Actual Use through Effort Expectancy of M-commerce services which is consistent with prior research. This result indicates that Jordanian consumer wants M-commerce to be easy-to-use and user-friendly interface to attain gains performance to accept and use of it. Fourth, Facilitating Conditions have no significant effect on Behavioral Intention to use M-commerce services. A possible explanation of this finding is that students in universities believe that the infrastructure such as hardware and software necessary to deal with M-commerce are exists. This conclusion corresponds with Thakur and Srivastava (2013). Fifth, according to moderating variables (gender, age, monthly expense, and experience) the results indicate that they are not supported so they did not influence the acceptance and use of M-commerce services. This conclusion corresponds with Foon et al. (2011). Excluding the age, Alkhunaizan and Love (2013) found that gender and education level are not supported, so they did not influence the acceptance and use of M-commerce in Saudi Arabia. Finally, as an ultimate aspiration, this study finds that there is a direct effect between behavioral intention and the eventual use of M-commerce services in Jordan. This indicates that consumers in Jordan are willing to accept and use M-commerce via concentrating on the above factors. The study could help in providing a platform for devising strategies, gives quantified indicators and presents a model that might help in understanding the M-commerce environment in Jordan. This study should help merchandisers avoid spending thousands or even millions of dollars that may on investments that will have little effect on whether or not the consumer will actually accept and use M-commerce services in Jordan. These conclusions lead us to encourage telecommunication industry and the investors to invest in M-commerce services in Jordan by focusing on the above factors. The study concludes with an examination of the implications of the research findings and offers suggestions for future research

\section{Recommendation for Future Research}

In order to gain further validation and generalization; this study would be conducted on other Middle East countries. Future studies can attempt to investigate other factors derived from the literature review to draw further broad view of the acceptance and usage of M-commerce among Jordanian consumers. Future studies may also attempt to investigate the effects of other moderating variables.

\section{References}

Abdelkarim, A., \& Nasereddin, H. (2010). Mobile Commerce. Journal of Mathematics and Technology, 4, $51-55$.

Alkhunaizan, A., \& Love, S. (2013). Effect of Demography on Mobile Commerce Frequency of Actual Use in Saudi Arabia. Advances in Information Systems and Technologies, 206, 125-131. http://dx.doi.org/10.1007/978-3-642-36981-0_12

Anckar, B., Carlsson, C., \& Walden, P. (2003). Factors Affecting Consumer Adoption Decisions and Intents in Mobile Commerce: Empirical Insights. 16th Bled eCommerce Conference: eTransformation.

Campbell, D. T. (1960). Recommendations for APA test standards regarding construct, trait, or discriminant validity. The American Psychologist, 15, 546-553. http://dx.doi.org/10.1037/h0048255

Chaffey, D. (2009). E-Business and E-Commerce Management: Strategy, Implementation and Practice (4th ed.). 
Pearson Education Limited.

Chin, W. W., Marcolin, B. L., \& Newsted, P. R. (2003). A Partial Least Squares Latent Variable Modeling Approach for Measuring Interaction Effects: Results from a Monte Carlo Simulation Study and an Electronic-Mail Emotion/Adoption Study. Information Systems Research, 14(2), 189-217. http://dx.doi.org/10.1287/isre.14.2.189.16018

Cho, D. Y., Kwon, H. J., \& Lee, H. Y. (2007). Analysis of trust in internet and mobile commerce adoption. Proceedings of the 40th Hawaii International Conference on System Science, USA.

Davis, D., \& Cosenza, R. (1993). Business research for decision making. California: Wadsworth Publishing Company.

Davis, F. (1989). Perceived usefulness, perceived ease of use, and User Acceptance of Information Technology. MIS Quarterly, 13(3), 318-339. http://dx.doi.org/10.2307/249008

Davis, F., \& Venkatesh, D. (1995). Measuring user acceptance of emerging information technologies: An assessment of possible method biases. In 28th Annual Hawaii International Conference on System Sciences. Hawaii (pp. 729-736). IEEE computer society press, Los Alamitos, Calif.

Economides, A., \& Grousopoulou, A. (2010). Mobiles in education: students' usage, preferences and desires. Int. J. Mobile Learning and Organisation, 4(3), 235-252. http://dx.doi.org/10.1504/IJMLO.2010.033553

Fishbein, M., \& Ajzen, I. (1975). Belief, Attitude, Intentions and Behavior: An Introduction to Theory and Research. Boston: Addison-Wesley.

Fishbein, M., \& Ajzen, I. (1979). A Theory of Reason Action: Some application sand Implications. In Nebraska Symposium on Motivation, H. Howe and Page (Eds.), University of Nebraska Press (pp. 65-116). Lincoln, NB.

Foon, Y., \& Fah, B. (2011). Internet Banking Adoption in Kuala Lumpur: An Application of UTAUT Model. International Journal of Business and Management, 6(4), 161-167.

Fornell, C., \& Larcker, F. L. (1981). Evaluating Structural Equation Models with Unobservable Variables and Measurement Error. Journal of Marketing Research, 18, 39-50. http://dx.doi.org/10.2307/3151312

Hair, J. F., Black, W. C., Babin, B. J., \& Anderson, R. E. (2009). Multivariate data analysis. Upper Saddle River, NJ: Prentice Hall.

Hair, J., Babin, B., Money, A., \& Samouel, P. (2003). Essentials of Business Research Methods. Lehigh Publishing, Inc.

Je, H. C., \& Myeong-Cheol, P. (2005). Mobile internet acceptance in Korea. Internet Research, 15(2), 125-140. http://dx.doi.org/10.1108/10662240510590324

Kline, R. B. (1998). Principles and practice of structural equation modeling. New York, NY: The Guilford Press.

Kock, N. (2009). Warp PLS 1.0 User Manual. ScriptWarp Systems, Laredo Texas. Retrieved from http://www.scriptwarp.com/ warppls/UserManual.pdf

Lin, S., \& Wu, S. (2002). Exploring the Impact of Online Service Quality on Portal Site Usage. Proceedings of the 35th Hawaii International Conference on System Sciences, IEEE. http://dx.doi.org/10.1109/HICSS.2002.994223

Liu, I. F., Chen, M., Sun, Y., Wible, D., \& Kuo, C. (2010). Extending the TAM model to explore the factors that affect Intention to Use an Online Learning Community. Computers \& Education, 54(2), 600-610. http://dx.doi.org/10.1016/j.compedu.2009.09.009

Luarn, P., \& Lin, H. (2005). Toward an understanding of the behavioural intention to use mobile university. Computers in Human Behavior, 21(6), 873-891. http://dx.doi.org/10.1016/j.chb.2004.03.003

Malhotra, Y., \& Galletta, D. F. (1999). Extending the Technology Acceptance Model to Account for Social Influence: Theoretical Bases and Empirical Validation. Proceedings of the 32nd Hawaii International Conference on System Sciences.

Mulliah, A., \& Stroulia, E. (2009). Mobile devices for collaborative learning in practicum courses. International Journal of Mobile Learning and Organisation, 3(1), 44-59. http://dx.doi.org/10.1504/IJMLO.2009.023052

Nor Shahriza, A., Siti Hawa, D., \& Ramlah, H. (2006). Mobile phone applications in academic Library services: 
a students' feedback survey. Campus-Wide Information Systems, 23(1), 35-51. http://dx.doi.org/10.1108/10650740610639723

Nysveen, H., Pedersen, H., Thorbjornsen, H., \& Berthon, P. (2005). Mobilizing the brand. Journal of Service Research, 7(3), 257-276. http://dx.doi.org/10.1177/1094670504271151

O'Reilly, C., \& Chatman, J. (1986). Organizational Commitment and Psychological Attachment: The Effects of Compliance, Identification, and Internalization on Prosocial Behavior. Journal of Applied Psychology, 71, 492-499. http://dx.doi.org/10.1037/0021-9010.71.3.492

ORJI, R. (2010). Impact of Gender and Nationality on Acceptance of a Digital Library: An Empirical Validation of Nationality Based UTAUT Using SEM. Journal of Emerging Trends in Computing and Information Sciences, 1(2), 68-79.

Park, J., Yang, S., \& Lehto, X. (2007). Adoption and Usage of Mobile Technologies for Chinese Consumers. Journal of Electronic Commerce Research, 31(3), 196-206.

Priyambodo, L., Tjiptono, F., \& Suyoto. (2012). M-Commerce in Indonesia: Problems and Prospects. International Journal of Computer Applications \& Information Technology, 1(2), 71-76.

Qingfei, M., Shaobo, J., \& Gang, Q. (2008). Mobile Commerce User Acceptance Study in China: A Revised UTAUT Model. Tsinghua Science and Technology, 13(3), 257-264. http://dx.doi.org/10.1016/S1007-0214(08)70042-7

Telecommunication Regulatory Commission Jordan. (2013). Retrieved September 21, 2013, from http://www.trc.gov.jo

Tella, A. (2011). Predicting Users' Acceptance of E-Library from the Perspective of Technology Acceptance Model. International Journal of Digital Library Systems, 2(4), 34-44. http://dx.doi.org/10.4018/jdls.2011100104

Thakur, R., \& Srivastava, M. (2013). Customer usage intention of mobile commerce in India: an empirical study. Journal of Indian Business Research, 5(1), 52-72. http://dx.doi.org/10.1108/17554191311303385

Venkatesh, V., \& Morris, M. G. (2000). Why Don't Men Ever Stop to Ask for Directions? Gender, Social Influence and Their Role in Technology Acceptance and Usage Behaviour. MIS Quarterly, 24(1), 115-139.

Venkatesh, V., Morris, M. G., Davis, G. B., \& Davis, F. D. (2003). User acceptance of information technology: Towards a unified view. MIS Quarterly, 27(3), 425-478. http://dx.doi.org/10.2307/3250981

Yap, C. S., \& Hii, J. W. H. (2009). Factors Affecting the Adoption of Mobile Commerce in Malaysia. Icfai Journal of Information Technology, 5(3), 24-37.

\section{Copyrights}

Copyright for this article is retained by the author(s), with first publication rights granted to the journal.

This is an open-access article distributed under the terms and conditions of the Creative Commons Attribution license (http://creativecommons.org/licenses/by/3.0/). 